\author{
Martyna Miernecka \\ Uniwersytet Warszawski \\ ORCID: 0000-0003-2854-6155
}

\title{
„Teraz tam literaci jeżdżą, piszą albo nic nie robią”. Dom Pracy Twórczej w perspektywie geografii literackiej
}

W grudniu 1947 roku pomysłodawcy utworzenia Domu Pracy Twórczej w dawnej rezydencji Potulickich w Oborach - Ewa Szelburg-Zarembina, Leopold Lewin i Aleksander Wat - redagują w tej sprawie pismo do Ministra Kultury i Sztuki. Do inicjatywy pozytywnie odnosi się Jarosław Iwaszkiewicz, pełniący wówczas funkcję Prezesa Zarządu Głównego Związku Literatów Polskich. W swojej odpowiedzi stwierdza: „Jedną z najpilniejszych potrzeb życia literackiego jest posiadanie w najbliższej okolicy domu do pracy, z dobrą komunikacją, gdzie literaci warszawscy mogliby wykroić dwa, trzy dni w tygodniu na pracę twórczą. Nie wątpimy, że dobroczynne tego skutki dla naszego piśmiennictwa okazałyby się wnet doniosłe”. Związek Literatów Polskich uzyskuje akceptację władz, przejmuje majątek i przeprowadza remont. We wrześniu 1948 roku odbywa się uroczyste otwarcie oborskiego pałacu - pierwszego Domu Pracy Twórczej w powojennej Polsce.

Powstające w całym kraju instytucje, takie jak Dom Dziennikarza czy Dom Chemika były istotnymi częściami życia codziennego i polityki PRL. Dom Pracy Twórczej, skupiając oficjalne środowisko kulturalne, jednocześnie stanowił miejsce, w którym zderzały się różne temperamenty i postawy artystyczne. Sama definicja tej instytucji - to obiekt noclegowy, w którym są zapewnione właściwe warunki do wykonywania pracy twórczej i wypoczynku twórców, 
wykorzystywany również (głównie przez ich rodziny) jako ośrodek wczasowy - sugeruje pierwsze napięcia i sprzeczności. Decyzje artystów o wyjeżdżaniu (albo niewyjeżdżaniu) do Domów Pracy Twórczej, specyfika ich pobytów, analiza samej instytucji - refleksja nad tymi zagadnieniami może dać interesujący wgląd w napięcia epoki.

W swoim szkicu skupię się na stosunku do Domów Pracy Twórczej czterech pisarzy: Mirona Białoszewskiego, Leopolda Tyrmanda, Marka Hłaski i Tadeusza Konwickiego. Koncentrując się na ich wyborach twórczych i formach pisarskiej autokreacji, chciałabym zastanowić się nad charakterem ich pobytów w DPT i obrazach tej instytucji w ich dorobkach - a także nad związanym z tymi kwestiami statusem twórczym i egzystencjalnym każdego z nich. Jako reprezentatywny przykład Domu Pracy Twórczej wybrałam ten położony w podwarszawskiej wsi Obory, Dom Pracy Twórczej im. Bolesława Prusa - nie tylko dlatego, że wszyscy czterej pisarze korzystali z jego usług, lecz także ze względu na siłę zbudowanej wokół niego i kształtującej zbiorową wyobraźnię mitologii.

Oczywiście pozycje Białoszewskiego, Tyrmanda, Hłaski i Konwickiego w życiu kulturalnym PRL zmieniały się, a dynamika ich relacji z władzą wpływała także na decyzje o „służbowych” wyjazdach. Szkic ten nie będzie jednak szczegółowym i wiernym odtworzeniem chronologii - chodzi raczej o zarysowanie ujęcia antropologicznego DPT jako pewnego fenomenu kulturowego i podjęcie refleksji nad twórczymi przestrzeniami czterech pisarzy w kontekście związanych z tym miejscem idei.

DPT jest w takim ujęciu niezwykle ważnym punktem na mapie powojennego życia literackiego - na jego płaszczyznę nakładają się liczne biografie i teksty literackie, co nieustannie modyfikuje charakter tego miejsca. Struktury narracyjne mieszają się ze sobą, tworząc nie tyle palimpsest, co gęstą siatkę powiązań między miejscem, autorami i tekstami. Miejsce spotkania i zagęszczenia kulturowych znaków wydobywa, jak wskazuje Edward Kasperski, charakter poszczególnych elementów; nie dąży do homogenizacji, ale przeciwnie - różnicuje, odbija, naświetla, prowadzi ku efektom porównawczym (Kasperski: 63), rezygnując z jednoznacznych ocen i utartych podziałów.

Chciałabym zanalizować narracje wybranych pisarzy w kontekście wieloaspektowego, wielogłosowego obszaru geografii literatury. Złożony problem relacji miejsca i literatury można ująć, jak proponuje Elżbieta Rybicka, 
w perspektywie geografii środowisk literackich - miejsce staje się w tym ujęciu przestrzenią twórczą, umożliwiającą działalność literacką (Rybicka: 36). Badaczka rozwija dotychczasowe teorie przestrzeni i popularyzuje na gruncie polskim pojęcie geopoetyki, akcentując interakcje pomiędzy semantyką związaną z geografią i poetyką. Nie chodzi tylko o proste tropienie reprezentacji motywów geograficznych w literaturze, ale o to, co „pomiędzy”:

Geopoetyka [...] nacisk kładzie na dwie strony procesu interakcji, a więc, z jednej strony na doświadczenie miejsc (które siłą rzeczy zakłada podmiotowe zapośredniczenie) oraz na ich pojetyczne tworzenie, a z drugiej strony - odwracając kierunek - na aktywną rolę miejsc w owym doświadczeniu. Sfera „geo” nie jest bowiem tylko przedmiotem i wytworem literackich i kulturowych praktyk pojetycznych. "Geo" może być w takim samym stopniu siłą sprawczą, jak poiesis.

(Rybicka: 93)

Ważne są zatem obie strony procesu - zarówno podmiot tworzący obraz literacki, jak i miejsce geograficzne, które wpływa na „ja” danego utworu. Założenie takiej chiazmatycznej relacji odwołuje się do sprawczej, performatywnej siły kreacji artystycznej. Literackie techniki i strategie kreowania miejsc prowadzone są przez autorów jednocześnie w przestrzeni i poprzez przestrzeń. Ze względu na to, że wśród badanych autorów przeważa narracja pierwszoosobowa z dominującą własna perspektywą, strategie te skierowane są na autokreację twórców. Poza tym sam charakter miejsca, legitymizujący zawód literata, określa „wzorcową” tożsamość twórcy, każe się swoim bywalcom ustosunkować do wyznaczonych zasad.

Kulturowych opracowań oborskiego DPT brakuje - wyjątkowy pod tym względem jest szkic Marka Zaleskiego Obory, czyli o nowej pastoralności. Jednocześnie instytucja ta pojawia się w ogromnej liczbie wspomnień, występuje w filmach i powieściach. Jest miejscem akcji powojennego życia kulturalnego, staje się jego tłem. Chciałabym odwrócić tę perspektywę: wysunąć DPT na pierwszy plan, zastanowić się zarówno nad fizyczną, materialną przestrzenią oborskiego domu, jak i jego symbolicznym wymiarem, a także nad typami narracji, które jego przestrzeń wywołuje.

Strukturę tego tekstu uporządkują nadrzędne funkcje domu w Oborach i odpowiadające poszczególnym funkcjom gatunki mowy - zgodnie z projektem geokulturologii Wasilija Szczukina. Szczukin szczegółowym przedmiotem uwagi 
czyni miejsce-topos kultury rosyjskiej - dwór szlachecki. Dwór rozumiany jest przez niego jako „miejsce socjokulturowe”, które spełnia określoną funkcję społeczno-pragmatyczną. Badacz odwołuje się do myśli Michaiła Bachtina, w ciekawy sposób przekształca jego teorię gatunków: „miejsca socjokulturowe (świątynia, pałac, dworzec, dwór i tak dalej) nie są czymś innym jak gatunkami oswojonych przez człowieka lub stworzonych przezeń przestrzeni. Rzeczywiście, miejsca owe istnieją po to, aby coś »robić«, każde z nich spełnia nałożoną na niego przez człowieka wyraźnie określoną funkcję, której nie jest w stanie spełnić inne miejsce" (Szczukin: 38-39).

Szczukin skupia się na związku między określonymi, bachtinowskimi gatunkami mowy a miejscem, w którym dokonuje się akt mowy - określone miejsca tworzą według niego specyficzne gatunki. Podstawowym założeniem metodologicznym tej koncepcji jest istnienie pomostu pomiędzy miejscem, gatunkami zdarzeń w nim występującymi oraz ustnymi i pisemnymi gatunkami zachowania (w tym: werbalnego), które wiążą się z tym miejscem (Rybicka: 74). Zgodnie z tą koncepcją chciałabym zastanowić się nad "gatunkowością" Domu Pracy Twórczej w Oborach, przy czym rozpoznania te mają charakter rekonesansu.

\section{„Tiritiri tiri tam tam”, czyli praca}

W pierwszej kolejności wypada chyba postawić pytanie o to, czy w Domu Pracy Twórczej w ogóle się pracuje. Idylliczny zakątek, w którym praca łączy się z przyjemnością - oraz towarzyszący mu gatunek sielanki - to chyba pierwszy trop skojarzeń z tą przestrzenią. Tak interpretuje ten świat Marek Zaleski DPT jawi się jako miejsce, w którym problematyczne rozdarcie twórcy między publicznym a prywatnym oraz między związkiem ze wspólnotą a marzeniem o autonomii zostaje zatarte; pisarz uwalnia się od poczucia alienacji od mas pracujących, a materialne niedostatki zostają zniesione. Wizja takiego miejsca jest oczywiście częścią socjalistycznego mitu - instytucja Domów Pracy Twórczej powstała w latach 20. w Związku Radzieckim i miała stanowić odbicie ustanowionego w nim ładu świata.

Zgodnie z ideą pracy w Domu Pracy Twórczej słychać, rzecz jasna, przede wszystkim dźwięki stukania na maszynie do pisania. To dominujące wrażenie 
zmysłowe w tej przestrzeni - Białoszewski opiera nawet kompozycję utworu Wczasy w Oborach na rytmie wyznaczonym przez tempo tych odgłosów. Utwór zachował się tylko w formie nagrania, na którym można usłyszeć głos poety relacjonujący akustyczne zmiany zachodzące w domu. Początek pobytu przedstawia bardzo dynamicznie: „Wczasowicze-literaci. Idą, jedzą, wracają. Stututu na maszynach. Grupka w las. Idą, jedzą, siedzą, wracają na spacer. Trututu”. Wraz ze zbliżającym się końcem „turnusu” następuje spowolnienie akcji: „A jednak obok nikt już nie mieszka. I naprzeciw nikt. Już nie zaśpiewa wesoła maszyna: tiritiri tiri tam tam. Tylko ze środkowych drzwi słychać uparty klekot, ten sam co od początku: trututututu” (Białoszewski, 2019).

Białoszewski chyba jako jedyny z całej czwórki intensywnie pisze w Oborach - nie wynika to jednak z charakteru i funkcji tego domu, tylko z postawy artystycznej poety. Konwicki pracował tam tylko raz - mroźną zimą przełomu lat 1954 i 1955 pisał Z oblężonego miasta. "Ta książka zapeszyła mi Obory”, wspominał we Wschodach i zachodach księżyca (Konwicki, 1990: 174-175). Nie znaczy to, że przestał korzystać z usług DPT - wprost przeciwnie. Swobodnie poszerzał zakres innych aktywności w tej przestrzeni („Można powiedzieć, że byłem złym duchem Obór”, Bielas, Szczerba: 138), usiłując prześcignąć w ekstrawagancjach innych twórców - a konkurencja była silna. Obowiązki służbowe nudziły też Hłaskę, natomiast Tyrmand wykorzystywał scenerię domów twórczo -wypoczynkowych Związku Literatów do zgoła innych scen swoich powieści.

Wydaje się, że Dom Pracy Twórczej miałby być przede wszystkim miejscem legitymizacji twórczego zawodu. Samo prawo do bycia tam określa tożsamość twórcy, może go też wywyższać. Tymczasem żaden z czterech interesujących mnie pisarzy nie przyznawał się do aspiracji do pozycji zawodowego pisarza.

Hłasko konstruował literacki autoportret, stylizując się na przykład w ankiecie członkowskiej Związku Literatów Polskich na samouka z proletariackich środowisk: „Niewykształcony szofer, który w wolnych chwilach po pracy próbuje opisać swoje życie” i na idiotę: „Trzykrotnie usiłowałem skończyć IX kl., lecz za każdym razem bez powodzenia. Usunięto mnie wreszcie, uważając za idiotę" (Czyżewski: 131).

Konwicki nieustannie ironizował: „Oczywiście [...] ja byłem czcigodnym, majestatycznym literatem, co to się wadzi z Bogiem i historią, chadza na spacery w słomkowym kapeluszu, a później peroruje tubalnym głosem o poezji rozparty 
w fotelu” (Konwicki, 1990: 160-161), a wyobrażając sobie „pociąg specjalny naszej literatury", sytuował siebie za wagonami literackimi trzeciej klasy i za wagonami towarowo-osobowymi: „na końcu towosu obok ubikacji zobaczyłem swój blady zewłok" (Konwicki, 1989: 168).

Dla Białoszewskiego twórczość była sposobem egzystencji. Nie oddzielał on pracy od wypoczynku, tego, co publiczne, od prywatnego, pisał wszędzie i nieustannie - jak w znanym fragmencie Szumów, zlepów, ciagów: „Wpadam w tramwaj. Zapisuje. Wysiadka, wysepka, zapisuje. Na Foksal tez. Który to autor robi przed wydawnictwem? A ja jeszcze piszęna schodach" (Białoszewski, 1989: 5). Nawet jeśli początkowo był niechętny przebywaniu w Domu Pracy Twórczej - relacjonuje nierówny rytm swojego nastawienia do nowego miejsca w Tajnym dzienniku: „Od razu odechciało mi się tych Obór. A potem się uspokoiłem i pomyślałem, że trzeba przezwyciężyć i siebie, i to, co dookoła” (Białoszewski, 2012: 506) - to nie przestaje w nim tworzyć. Nagranie Na wczasach $w$ Oborach wydobywa sytuacyjność pisanego w DPT utworu, podkreśla zainteresowanie rodzajowością dziejących się tam zdarzeń, wreszcie - raz jeszcze ukazuje niezwykłą wrażliwość poety na przestrzeń. Białoszewski nazwał ten utwór swoją „nową formą”, komentując: „- Nazwałem to poemat - to tak na pograniczu prozy, wiersza. Trudno określić” (Stańczakowa: 299). Wyjazd nie wytrąca go więc z własnego stylu pracy twórczej, wręcz przeciwnie - nowe miejsce odświeża percepcję i zachęca do eksperymentowania. Jednocześnie Białoszewski zachowuje dystans do pozycji zawodowego literata, co podsumował w tytule jednego z utworów z tomu Polot nad niskimi sferami: Obory / gdzie dziś wszelcy i wszlafrocy literaci.

Spośród nich to Tyrmanda chyba najbardziej pociągał autorytet twórcy. Nie godził się jednak na „transakcje z reżimem” (Tyrmand, 2015: 53) i nazywał siebie bezrobotnym:

Co nie znaczy, że nie pracuję: przeciwnie, pracuję intensywniej i wydajniej od innych, lecz na zewnątrz skonstruowanego przez komunistów perpetuum mobile. Mój luksus zbudowany jest na dwóch pylonach wolności i jednym poczuciu wyjątkowości. Pylony to: wolność od dyscypliny pracy i wolność od zajęć pozasłużbowych. Poczucie wyjątkowości zasadza się na Schadenfreude: jakże mało jest w tym kraju takich facetów jak ja.

(Tyrmand, 2015: 53) 
Sprzeciwianie się służbowemu wymiarowi pracy pisarza ustawi już w punkcie wyjścia charakter wyjazdów Tyrmanda do DPT - będą służyły one autokreacji outsidera w kolorowych skarpetkach - przeklętych i do znudzenia przywoływanych, jak określiła je Kornelia Sobczak w tomie „Ceglane ciato, goracy oddech". Warszawa Leopolda Tyrmanda.

Choć wszyscy czterej odżegnywali się od wizerunku zawodowego literata, zależało im na przynależności do Związku Literatów Polskich. „Chyba mnie wyleją" (Tyrmand, 2015: 261), martwi się Tyrmand przy okazji komisji kwalifikacyjno-weryfikacyjnej, mając na uwadze przede wszystkim tanie obiady w stołówce Literatów. Białoszewski i Hłasko także korzystają z przywilejów członkostwa w ZLP, Konwicki przez pewien czas pełni nawet funkcję sekretarza warszawskiego oddziału. Niezależnie więc od wysoko przez nich cenionego poczucia indywidualizmu, funkcjonowali w obrębie oficjalnego życia kulturalnego PRL. Jako członkowie Związku mogli brać w nim czynny udział. Robili to jednak na własnych warunkach - interesujące mnie pytanie dotyczy form poszerzania obszarów swojej niezależności w ramach tej struktury.

\section{„Żeby nikt nie widział”, czyli wczasy w więzieniu}

„Świeże miejsce. Na nieznanych sprężynach” - pisze Białoszewski w październiku 1976 roku na początku swojego pierwszego pobytu w Oborach. Miejsce jest nowe i obce, wyjazd zakłada pewną odświętność sytuacji, na którą pisarze zwracają uwagę za każdym razem. Dla Konwickiego podróż w 1981 roku do DPT w Konstancinie wiąże się z bezsennością, chorobami, nerwami i różnymi innymi dolegliwościami: „Odbywam daleką, romantyczną podróż. Pojechałem do Konstancina, piętnaście kilometrów od centrum Warszawy. A wybierałem się jak do Australii” (Konwicki, 1990: 154). Sama podróż jest wstępem do pobytu w DPT, wytrąca z codziennego rytmu życia i zrywa z tradycyjnie ujmowanym czasem. Może być wręcz pewnym obrzędem przejścia - pokonanie tego dystansu otwiera nową, inną przestrzeń.

Konwicki wyjeżdża pod Warszawę, „żeby nikt nie widział” (Konwicki, 1990: 17), gdzie może na przykład bezwstydnie wrócić do swojego utworu z przełomu lat 40. i 50. Dom, do którego można uciec, w którym można się ukryć - to aspekt wyjątkowo cenny także z perspektywy Marka Hłaski, który 
w różnego rodzaju oficjalnych instytucjach znajdował "przytuliska”. Obraz Obór jako bezpiecznego schronienia dominuje bezpośrednio po wojnie w kontekście „bezdomności” pisarzy (np. w zapiskach Aleksandra Wata).

Z pierwszych spostrzeżeń twórców można jednocześnie wywnioskować, że wyjazd do DPT przypomina wakacje. Z jednej strony rytm pobytu w Oborach budzi skojarzenia z turnusami wczasowymi - paradoksalnie kojarzy się raczej z beztroską niż wytężoną pracą. Z drugiej strony, podobnie jak w domach wczasowych, rządzi w nim sformalizowany regulamin pobytu, który zaznacza pewną opresyjność miejsca, a obecność czuwających nad tym regulaminem kierowniczek podkreśla sztuczność systemu i wydobywa jego teatralny charakter. Jedna z kierowniczek przypomina Białoszewskiemu Lady Makbet: „Pani kierowniczka blada / w sukni do ziemi siada" (Białoszewski, 2017b: 116), natomiast obsługujące są „hoże, jak nie z tych czasów” i „podobno gardzą literatami” (Białoszewski: 2019). Wszyscy odgrywają swoje role w tym spektaklu, którego sceną może być każdy z zakamarków pałacu i parku, z pewnością zaś sala jadalniana, w której - według licznych anegdot - zajmowane przy stole miejsce miało odwzorowywać porządek rang i autorytetów (Zaleski, 2007). To zresztą analogia do tyrmandowskiego „żelaznego podziału stolików” na obiadach u Literatów - z tym, że w jego ujęciu kelnerki stanowią zagrożenie, bo znają wszystkie „kosztowne grzeszki” gości (Tyrmand, 2016: 356).

Czasoprzestrzeń DPT rządzi się więc własnymi regułami, do których kuracjusze muszą się dostosować. Jednocześnie obowiązujące tu zasady - zarówno oficjalne, jak i niepisane - przekształcane są przez mieszkańców zgodnie z ich oczekiwaniami i potrzebami. Białoszewski, w kontrze do panującego w DPT trybu życia, nie rezygnuje ze swoich codziennych przyzwyczajeń i manipuluje nową sytuacją przestrzenną. Jego praktyki - znane z innych utworów i miejsc - budzą ciekawość całej wspólnoty, którą mają kształtować twórcy. Krystyna Kolińska, eseistka i pisarka, w tekście Parnas w Oborach wspominała z przejęciem obserwowane przez nią zaciemnianie okien w pokoju, znoszenie tam liści, kwiatów, zielsk czy spacerowanie nocą:

Siedemnastkę objął po mnie kiedyś Miron Białoszewski, a gdy opuścił pokój po miesiącu, natychmiast tam wróciłam. Nie zdążono jeszcze wynieść porozwieszanych gałęzi, pęków ziół, zasuszonych kwiatów, pozostawionych przez niezwykłego poetę. Pani Tereska Marciniak, sprzątając, informowała mnie z przejęciem: „Śpi, 
moja kochana pani, w dzień, przy zamkniętych i całkiem zasłoniętych oknach. Pełno tu zawsze takich zielsk, liści. Nocą to on chodzi - tu pani Tereska uczyniła znak krzyża - na cmentarz, aż do Słomczyna; tam są grobowce Potulickich. Często mi mówi: »Niech pani się ze mną, pani Teresko, tam wybierze. Umarli krzywdy nie robią... Spokój jest, cisza....".

(Kolińska: 19)

Białoszewski oswaja obce miejsce i podejmuje grę z obowiązującą tu etykietą. Hłasko też się nią nie przejmuje - kiedy przyjeżdża do Obór w 1954 roku na Zjazd Młodych, walczy przede wszystkim... z nudą:

Niewiele już pamiętam z tego zjazdu; mówiono znowu dużo o typowości w literaturze; my z kolegą Bernsteinem spaliśmy na zmianę: on pięć minut, ja pięć minut, po czym jeden budził drugiego. $\mathrm{Z}$ daleka wyglądało to dobrze; jeden z twarzą ukrytą w dłoniach i pogrążony w głębokiej kontemplacji; drugi siedzący sztywno z wytrzeszczonymi oczyma - jak to powiada Szwejk - jak kocur srający w sieczkę. Po czym następowała zmiana; jeden budził drugiego i ten z kolei zaczynał wytrzeszczać oczy, a drugi chował twarz w dłoniach. Po zakończonych obradach szliśmy znów z Bernsteinem na nocne uciechy.

(Hłasko: 28)

Hłasko nie dostosuje się łatwo do reguł życia w DPT. Bardziej niż poszczególnymi miejscami będzie zainteresowany przemieszczaniem się pomiędzy nimi. Ruch ten, dyktowany dynamiką bogatego życia towarzysko-uczuciowego z jednej strony, a z drugiej - odruchem ucieczki od ludzi, nie pozwoli na związanie się z miejscem, zwłaszcza z takim, w którym dochodzi do paradoksalnego sprzężenia swobodnej twórczości i przestrzeni silnie znormatywizowanej. Z podobnym nastawieniem pisarz będzie traktował także pobyt w siedzibie Instytutu Literackiego w Maisons-Laffitte, na co zwracała uwagę Clara Zgoła w tekście z tomu Sto metrów asfaltu. Warszawa Marka Htaski. Odświętny, wspólnotowy wymiar funkcjonowania w tej mikrospołeczności pod wieloma względami przypomina DPT. Sposób funkcjonowania Hłaski w tych domach będzie stanowił istotny składnik legendy pisarza, uwzględniającej także styl pracy twórczej i praktyki odpoczywania od niej.

„Wczasowicze-literaci” zwalczają obowiązujące w tej instytucji zasady, nudny rytm dnia i nocy oraz swoje obowiązki. Zdaje się, że regulamin DPT zawiera w sobie przyzwolenie na wykraczanie poza własne ramy. Być może, jak w karnawale, porządek zostaje tu odwrócony - w końcu dość znamienne są 
liczne anegdoty o pomyłkach przy wyznaczaniu miejsc przy stołach w jadalni. Odgórny system tej „stołówkowej geografii”, jak stwierdzał Zaleski, miał legitymizować centralną, zarówno administracyjną, jak i duchową, władzę instytucji państwowych, w praktyce zaś został wypełniony towarzyskimi czy politycznymi gafami.

Władza - obok zaskakującej atmosfery swobody i zabawy - była wyraźnie obecna. Bardziej drastyczny wyraz opresyjności polityki i obraz sytuacji, w jakiej mieli funkcjonować literaci, przedstawia Konwicki w opowieści o poszukiwaniu dezertera przez armię radziecką w czasie jego pobytu w Oborach:

Więc nagle, jednego dnia na początku czerwca, w samym apogeum wiosny, szalonej nadwiślańskiej wiosny, może już ostatniej takiej wiosny, a więc raptem któregoś rana zaczęły latać nad Oborami wojskowe helikoptery ze znakami radzieckimi. Samo przez się zrozumiałe, że jesteśmy kolonią i naszym panom wolno latać nad nami, ale na ogół Rosjanie przestrzegają odrobinę form, nie świecą sowieckością w oczy w stolicy państwa, które uchodzi za niepodległe. Te helikoptery latały tam i z powrotem, agresywne, hałaśliwe, czegoś bardzo rozeźlone. $Z$ tego latania tam i siam wyłaniał się z wolna jakiś niepokój, coś w rodzaju histerii, którą pamiętam z trzydziestego dziewiątego roku.

(Konwicki, 1990: 159)

To katastroficzna, wręcz apokaliptyczna wizja. Napięcie pomiędzy słoneczną, idylliczną przestrzenią, aurą enklawy wolności a sytuacją uwięzienia jest bardzo wyraźne i - co więcej - charakterystyczne dla całej epoki. Funkcjonowanie takich instytucji jak DPT wynikało z poparcia władz PRL dla aktywności dających „światu pracy” zdrowie i zadowolenie i było tym uzasadniane, ale wiązało się także z ideologiczną taktyką. Zwraca na nią uwagę Tyrmand, kiedy zastanawia się nad celem zebrań literackich w ZLP. Oprócz pouczania pisarzy, jak pisać, według niego zebrania „pozwalają wygadać się pisarzom trapionym przez obiekcje”, co ma na celu „bezpieczne wentylowanie smrodliwych frustracji bez zatruwania nimi społeczeństwa, kanalizowanie i odprowadzanie nieczystości myśli w cuchnące błotko izolowanej od narodu literackiej kloaki” (Tyrmand, 2015: 109).

Wraz z końcem zebrań literackich, o których z takim zainteresowaniem pisał Hłasko, następował czas „nocnych uciech”, który stanowił chyba najistotniejszą część pobytu w DPT - i potwierdzał jego karnawałowy charakter. 


\section{„Zakątki, kryjówki, schowki, ostępy, mateczniki, chaszcze”, czyli seks}

Kontekst życia erotycznego Domów Pracy Twórczej jest wyraźny w zapiskach wszystkich czterech pisarzy. Białoszewski odwołuje się do historii Obór, a konkretnie do postaci Marii Anny de La Grange d'Arquien, siostry królowej Marii Kazimiery Sobieskiej, trzeciej żony Jana Wielopolskiego, którą Sobieski „wrzucił [...] do dworku z sadzawkami, z komarami, bo źle sie, prowadziła” (Białoszewski, 1991: 25). Okolice Obór kojarzą się erotycznie także Konwickiemu i Hłasce. Tyrmand skupia się raczej na Domu Związku Literatów w Zakopanem. Astoria pojawia się w Dzienniku 1954 w związku z romansem z Bronką jako „przystań marzeń”, „oaza snobizmu, rezerwat prestiżu” (Tyrmand, 2015: 310). Może stanowić miejsce i narzędzie flirtu, pisarz w końcu znajduje się na swoim gruncie, ma przewagę, bo zna tu każdy kąt i zrutynizowaną mechanikę codzienności. Jeśli pojawia się tu motyw zebrania literackiego, to tylko jako oficjalna wymówka odwołania spotkania z Basią, żeby umówić się na schadzkę z Bronką. Do końca pobytu „były już tylko hulanki, biesiady i zazdrość” (Tyrmand, 2015: 313). Podobne funkcje pełni Astoria w Życiu towarzyskim i uczuciowym. Dzięki znajomościom Andrzej otrzymuje pokój w tym domu pełnym wysoko postawionych osobowości i w nim odgaduje społeczne zasady funkcjonowania towarzystwa, co prowadzi go do „wdarcia się do klanu po ciałach kobiet” (Tyrmand, 2016: 211).

To, co niewątpliwie sprzyja erotycznym przygodom, to położenie geograficzne Obór, które w oczach Konwickiego jawi się jako bujna, zdziczała roślinność, budząca skojarzenia z dziewiczością sprzed powstania miast. Konwicki obserwuje tam z Adamem Bahdajem zwierzęta i mitologizuje przestrzeń na swój sposób: „całe to dno Prawisły wokół Obór to był jakiś prawie afrykański rezerwat odwiecznej, błotnej, dzikiej przyrody, raj ogromnych ilości gatunków ptasich, które tu rodziły się i umierały” (Konwicki, 1990: 156-157). Z jego perspektywy to - oczywiście! - dolina, czasem - wyspa, na której jeszcze słychać odgłosy zwierząt, ale już niedługo wkroczą na nią „profesorowie i docenci” oraz maszyny, którymi zaczną „ryć w ziemi, kłaść rozbite rury, karczować drzewa”, co wywoła „pierwsze objawy pustynnienia” (Konwicki, 1990: 158). 
Jednak zanim „dno Prawisły” - obejmujące, co istotne, także Dom Pracy Twórczej Stowarzyszenia Autorów ZAIKS - uległo destrukcji, stanowiło przestrzeń eksplorowaną przez „hipisoterrorystów”:

A więc były tu różne zakątki, kryjówki, schowki, ostępy, mateczniki, chaszcze. $\mathrm{Na}$ plażach, ostrogach, łachach, wyspach. Nad wartkim nurtem rzeki i nad gnijącymi odnogami pozostałymi po wiosennej powodzi. W soczystych kwaśnych trawach oraz na plażach wymoszczonych najczystszym w świecie piaskiem krzemowym.

(Konwicki, 1990: 161)

Z perspektywy Białoszewskiego główną zaletą turnusowych romansów były plotki. To one, jak stwierdza podczas jednego ze wspólnych pobytów w Oborach Julia Hartwig, działają na niego bardziej niż poezja (Białoszewski, 2012: 434). To na obgadywaniu domu i jego mieszkańców upływa Białoszewskiemu czas. Plotkuje z Meksykanką, czyli Krystyną Rodowską, poetką, tłumaczką z języka hiszpańskiego i francuskiego, wieloletnią redaktorką działu hiszpańskojęzycznego „Literatury na Świecie”. Ich zainteresowanie budzi m.in. małżeństwo Włodzimierza Słobodnika, poety, satyryka, tłumacza z języka rosyjskiego, i Eleonory Słobodnikowej, tłumaczki literatury rosyjskiej - małżeństwo dość burzliwe, opisywane także przez Krystynę Kolińską w Parnasie w Oborach. W przypadku Białoszewskiego to podsłuchiwanie, gawędzenie, zestrajanie różnych głosów jest oczywiście strategią bycia w świecie, a sam proces pisania formą współuczestnictwa w dzianiu się tego świata (Burkot: 92). Taka strategia ma szczególny wydźwięk w Domu Pracy Twórczej - poeta przedrzeźnia przecież literaturę w salonie literatury. Występuje tym samym przeciwko jej instytucjonalizacji, robi to wbrew fetyszyzacji osoby autora - a procesy te osiagają, jak się wydaje, punkt kulminacyjny w Oborach. Białoszewski dystansuje się od tego i obnaża sztuczną dekoracyjność tego miejsca - ale o tym za chwilę.

\section{Na pół uprzejma, na pół kwaskowa”, czyli gra z konwencją}

W kontekście badania oborskiego DPT istotny jest charakter jego założenia architektonicznego. Kompleks pałacowy wybudowany został w latach 80 . XVII wieku dla Jana Wielopolskiego, kanclerza wielkiego koronnego, męża 
siostry królowej Marysieńki, o której była już mowa. Wśród potencjalnych autorów projektu tego założenia obejmującego dwór, oficynę, browar, a także park ze stawem wymienia się Tylmana z Gameren, ewentualnie kogoś inspirującego się nim.

Zabytkowy charakter pałacu w Oborach, najpierw, w 1945 roku, zajętego przez Państwowe Zakłady Chowu Koni, a następnie przejętego przez Związek Literatów Polskich, uruchamiał szczególne, historyzujące narracje pisarzy na temat tego miejsca. Często wspomina się na przykład o tamtejszym koniu, który nazywał się Pomidor. Zaprzęgany do fury, miał wozić pensjonariuszy na przystanek autobusowy albo odbierać ich i zabierać do Obór. W opowieściach pojawia się też motyw mroźnej zimy i odcięcia elektryczności we wsi. Występuje przede wszystkim w wypowiedziach Konwickiego, który wspominał: „Byliśmy jak w jakimś starym dworze w XIX wieku, odizolowani od świata, zasypani śniegiem (Bielas, Szczerba: 137). Takie aluzje są bliskie Konwickiemu:

A potem nagle budziłem się i wracałem do Obór, gdzie łoskotały maszyny do pisania wystukujące wiersze i powieści, które już dawno umarły. A potem wchodziłem w cieniste aleje parku (tak bywało w dawniejszych książkach) i w tych alejach spacerowali albo siedzieli na pobrzeżach trawników moi koledzy, którzy dawno umarli albo jeszcze do dzisiaj wspinają się pracowicie na Olimp, co go przecież nie ma, co został kiedyś przez kogoś rozebrany.

(Konwicki, 1990: 157-158)

DPT w Oborach nasuwał skojarzenia z dworkiem szlacheckim - kolejnym gatunkiem tej przestrzeni byłaby gawęda - jednak w kontekście socjalistycznego mitu, który miał się w nim spełnić, wydobywanie szlacheckiej aury wydaje się po prostu ironiczne.

Z kiczem takiej stylizacji z pewnością grał Marek Hłasko. Na elegancką, cukierkową iluzję DPT reagował młodzieńczym „zgrywaniem się”. Na specyfikę jego strategii zwracał uwagę Konwicki:

Mieszkaliśmy wtedy w domu literatów w Oborach pod Warszawą. Animował nas tam i czarował Mareczek Hłasko, w pełni sił, w sztosie natchnienia, w pierwszym kroku przez chmury. Jednego wieczoru zniknął nagle i nikt nie wiedział, kiedy zniknął i na jak długo zniknął. Znikał zresztą dosyć często i powracał z jakąś niespodzianką.

(Konwicki, 1989: 91) 
Mistyfikacje Hłaski były składnikami jego procesu twórczego i swoistymi performance’ami w życiu codziennym - pisała o nich Weronika Parfianowicz -Vertun w tomie Sto metrów asfaltu - zdaje się, że praktyki te na tle oficjalnego charakteru DPT miały jeszcze mocniejszą siłę rażenia. Pod wpływem zgrywy pisarza, który nabiera pensjonariuszy, że umarła mu córka, „zrobił się ogromny ruch w Oborach" i do zinstytucjonalizowanej formy DPT wprowadzony zostaje tym samym element gry.

Białoszewski, jeszcze przed swoim pierwszym wyjazdem do Obór, w trakcie pobytu w pobliskim sanatorium, wyobrażał sobie to miejsce następująco: „Teraz tam literaci jeżdżą, piszą albo nic nie robią. Chodzą po krowiej drodze całej w żebra z zaschniętego błota” (Białoszewski, 1991: 25). Dystans do „salonu literatury" przejawia się w samym sposobie percypowania tej przestrzeni uwaga Białoszewskiego skupia się wokół rejonów marginalnych: zauważa przede wszystkim „błota, komary, krowy” (Obory/gdzie dziś wszelcy i wszlafrocy literaci z tomu Polot nad niskimi sferami, Białoszewski, 2017a: 114).

„Błotniste” rejestry Białoszewski kontrastuje z dworskim charakterem założenia pałacowego Obór (by wspomnieć raz jeszcze zapiski na temat kierowniczek DPT - w Tajnym dzienniku tak opisuje Maję Neuman: „Księżna to kierowniczka tutejszego domu literatów, tak zwanego twórczego. Jest na pół uprzejma, na pół kwaskowa. Tym bardziej księżna”, Białoszewski, 2012: 516). Wynik zestawienia obu rejestrów jest, rzecz jasna, śmieszny - tak samo, jak odgrodzenie murem kompleksu DPT od rozciągającej się wokół niego przestrzeni oborskiego PGR. Zarówno błoto, które ciągle powraca w pisaniu Białoszewskiego, jak i „spustoszone ogrodnictwo, połamane kasztany alei, mocno nadniszczony park”, na które zwraca uwagę Konwicki (1990: 174) sprawiają, że Obory już w punkcie wyjścia stawały się miejscem poddawanym łatwej parodii.

Dom Pracy Twórczej jako pewien fenomen kulturowy miał dialektyczny charakter, który oscylował pomiędzy więzieniem i azylem. Ten specyficzny rodzaj przestrzeni w załozieniu miał tworzyć zwartą wspólnote_- „falanster naszej biednej literatury”, jak pisał Konwicki - w praktyce zaś ujawniał całe spektrum wrażeń 
rozciągających się pomiędzy tęsknotą za samotnością, dającą wytchnienie, a potrzebą posiadania odosobnionego kąta, który może stać się miejscem izolacji.

Analiza sposobów posługiwania się Domem Pracy Twórczej przez Białoszewskiego, Tyrmanda, Hłaskę i Konwickiego wydobywa konfliktowy rozdźwięk między projektem wyzwolenia jednostki, realizującej się twórczo w danym miejscu, a karykaturalnymi elementami wcielenia tego projektu w życie. Wszyscy czterej pisarze - mimo różnic w ich autorskich spektaklach zwracali uwagę na cechy wyróżniające DPT jako szczególną instytucję kultury. Sposoby wykorzystywania przez nich tej przestrzeni zazębiały się; ich działania i narracje wchodziły ze sobą w interakcję, tworząc gęstą siatkę powiązań. Dom występował w funkcji przestrzeni twórczej, umożliwiającej działalność literacką; w funkcji schronienia bądź więzienia; wyłaniał się jako miejsce zabawy, skupiając jak w soczewce ówczesne życie towarzyskie. Związane z funkcjami domu formy narracji wykorzystują konwencje sielanki, flirtu, plotki czy szlacheckiej gawędy. Gatunki te były z jednej strony związane ze specyfiką fenomenu kulturowego, jakim był Dom Pracy Twórczej, z drugiej - wpływały na sposób postrzegania tego domu, budowały jego mit w imaginarium kulturowym.

Wielość działań o charakterze politycznym, artystycznym bądź towarzyskim podejmowanych w Domach Pracy Twórczej skłania do refleksji nad podziałami na sfery: oficjalne i nieoficjalne, prywatne i publiczne, zaangażowane i niezaangażowane. Białoszewski, Tyrmand, Hłasko i Konwicki rozbijają abstrakcyjność i arbitralność tych rozgraniczeń. Literatura przez nich tworzona sprawnie rozgrywa napięcia wywoływane przez charakter DPT i na przekór zagrożeniom z nim związanym nieustannie stwarza ten dom od nowa.

\section{Bibliografia}

Białoszewski, Miron. Konstancin. Warszawa: Państwowy Instytut Wydawniczy, 1991. Polot nad niskimi sferami. Warszawa: Państwowy Instytut Wydawniczy, 2017a.

------. Proza stojaca, proza lecąa. Warszawa: Państwowy Instytut Wydawniczy, 2015.

------. Szumy, zlepy, ciagi. Warszawa: Państwowy Instytut Wydawniczy, 1989.

Świat mozna jeść w kazdym miejscu. Warszawa: Państwowy Instytut Wydawniczy, 2017b. 
------. Tajny dziennik. Kraków: Znak, 2012.

------. Wczasy w Oborach [audio]. https://www.piw.pl/bialoszewskiaudio [dostęp: 20.06.2019].

Bielas, Katarzyna, Jacek Szczerba. Pamiętam, że byto goraco. Rozmowa z Tadeuszem Konwickim. Wołowiec: Wydawnictwo Czarne, 2015.

Burkot, Stanisław. Miron Biatoszewski. Warszawa: Wydawnictwa Szkolne i Pedagogiczne, 1992.

Czyżewski, Andrzej. Piękny dwudziestoletni. Warszawa: Prószyński i S-ka, 2012.

Hłasko, Marek. Piękni dwudziestoletni. Warszawa: Polityka Spółdzielnia Pracy, 2008.

Kasperski, Edward. Kategorie komparatystyki. Warszawa: Wydawnictwo Wydziału Polonistyki UW, 2010.

Kolińska, Krystyna. Parnas w Oborach. Warszawa: Prószyński i S-ka, 2000.

Konwicki, Tadeusz. Nowy Świat i okolice. Warszawa: Czytelnik, 1986.

-----. Kalendarz i klepsydra. Warszawa: Czytelnik, 1989.

------. Wschody i zachody księżyca. Warszawa: Wydawnictwo Officyna, 1990.

Parfianowicz-Vertun, Weronika. „Jamesa Deana trapi lumbago albo o fatalnych skutkach (nie)posiadania własnego kąta”. Sto metrów asfaltu. Warszawa Marka Htaski. Red. Agnieszka Karpowicz, Piotr Kubkowski, Włodzimierz Karol Pessel, Igor Piotrowski. Warszawa: Lampa i Iskra Boża, 2016.

Rybicka, Elżbieta. Geopoetyka. Przestrzeń i miejsce we wspótczesnych teoriach i praktykach literackich. Kraków: Universitas, 2014.

Szczukin Wasilij. Mit szlacheckiego gniazda. Studium geokulturologiczne o klasycznej literaturze rosyjskiej. Tłum. Bogusław Żyłko. Kraków: Universitas 2006.

Sobczak, Kornelia. „Siedem dalekich rejsów. Flirt (z) gatunkiem”. „Ceglane ciato, goracy oddech". Warszawa Leopolda Tyrmanda. Red. Agnieszka Karpowicz, Piotr Kubkowski, Włodzimierz Karol Pessel, Igor Piotrowski. Warszawa: Lampa i Iskra Boża, 2015.

Stańczakowa, Jadwiga. Dziennik we dwoje. Wrocław: Warstwy, 2015.

Tyrmand, Leopold Dziennik 1954. Warszawa: Wydawnictwo MG, 2015.

-----. Żyie towarzyskie i uczuciowe. Warszawa: Wydawnictwo MG, 2016.

Zaleski, Marek. „Obory, czyli o nowej pastoralności”. Tegoż, Echa Idylli w literaturze polskiej doby nowoczesności i późnej nowoczesności. Kraków: Universitas, 2007. 
Zgoła, Clara. „Skompromitowana stolica kulturalna świata i podmiejski falanster. Paryż i Maisons-Laffitte Marka Hłaski”. Sto metrów asfaltu. Warszawa Marka Htaski. Red. Agnieszka Karpowicz, Piotr Kubkowski, Włodzimierz Karol Pessel, Igor Piotrowski, Warszawa: Lampa i Iskra Boża, 2016.

\title{
"Nowadays, Writers Go There, Write, or Do Nothing”. House of Creative Work in the Perspective of Literary Geography
}

\begin{abstract}
Summary
The purpose of this article is to analyze the cultural phenomenon of the House of Creative Work institution in the post-war Poland as demonstrated by the stays of four writers - Miron Białoszewski, Tadeusz Konwicki, Leopold Tyrmand, Marek Hłasko - in one of the Houses, Obory near Warsaw. A comparative analysis of the attitude of these writers towards the institution in question, as well as the transformational nature of the relation between its space and literary material creates a dense network of connections between the place, authors, and texts. The article is part of a research in the field of geopoetics and raises questions about the physical and material space of the House in Obory, its symbolic dimension, and the types of narratives that it evokes. The structure of this article is ordered by the primary functions of the house in Obory and the speech genres corresponding to particular functions according to the geoculturology project by Wasilij Szczukin.
\end{abstract}

Keywords: comparative literature, Polish literature, House of Creative Work, Obory, speech genres, geopoetics

Słowa kluczowe: komparatystyka literacka, literatura polska, Dom Pracy Twórczej, Obory, gatunki mowy, geopoetyka 